\title{
UJI EFEK ANALGESIK EKSTRAK ETANOL BUAH MENGKUDU (Morinda citrifolia L.) PADA MENCIT (Mus musculus)
}

\author{
Randy Nicholas Lesiasel \\ Henoch Awaloei \\ Jimmy Posangi \\ Fakultas Kedokteran Universitas Sam Ratulangi Manado
Email: Rancholas@yahoo.com
}

\begin{abstract}
Population Indonesia has long been known and used medicinal plants in effort to cope with health problems. Noni plant (Morinda citrifolia L.) is included in the medicinal plants that have been used for traditional medicine in Indonesia, one of them as analgesic. According Younos et al. (1990), noni extract has analgesic effect. Xeronine compound of the noni fruit is suspected to have an analgesic effect. The purpose of this study whether there analgesic effect of ethanol extract of noni fruit (Morinda citrifolia L.) in mice (Mus musculus). This study is an experimental study using heat stimuli such as temperature of $55^{\circ} \mathrm{C}$. This study used laboratory animals such as female mice which were divided into five groups, each consisting of three mices. Group I as negative control was given $0.4 \mathrm{ml}$ of distilled water, group II as positive control was given paracetamol $1000 \mathrm{mg} / 50 \mathrm{kgBB}$, group III as treatment group was given ethanol extract of noni fruit $200 \mathrm{mg} / \mathrm{kgBB}$, group IV as treatment group was given ethanol extract of noni fruit $400 \mathrm{mg} / \mathrm{kgBB}$ and group $\mathrm{V}$ as treatment group was given ethanol extract of noni fruit $800 \mathrm{mg} / \mathrm{kgBB}$. An observation was carried out for one minute with the expected response being jumping and licking its feet as a reaction to reduce the pain. From the experimental results by providing heat stimuli such as temperature of $55^{\circ} \mathrm{C}$ showed that the response of mice decreased in all thre treatment groups compared with the positive control which was given paracetamol.The ethanol extract of noni fruit(Morinda citrifolia L.) has an analgesic effect on mice (Mus musculus).
\end{abstract}

Keywords: Analgesic, Noni fruit (Morinda citrifolia L.), Paracetamol.

\begin{abstract}
Abstrak: Penduduk Indonesia telah lama mengenal dan menggunakan tanaman berkhasiat obat sebagai salah satu upaya dalam menanggulangi masalah kesehatan. Tanaman mengkudu (Morinda citrifolia L.) termasuk dalam tumbuhan obat yang sudah dimanfaatkan untuk pengobatan tradisional di Indonesia salah satunya sebagai analgesik. Menurut Younos et al. (1990), ekstrak mengkudu mempunyai efek analgesik. Senyawa xeronine yang terdapat pada buah mengkudu diduga mempunyai efek analgesik. Tujuan penelitian ini ialah mengetahui ada tidaknya efek analgesik dari ekstrak etanol buah mengkudu (Morinda citrifolia L.) pada mencit (Mus musculus).Penelitian ini ialah penelitian eksperimental dengan menggunakan

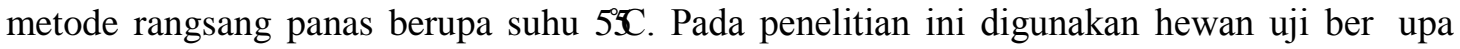
mencit betina yang dibagi dalam lima kelompok masing-masing terdiri dari tiga ekor. Kelompok I kelompok negatif diberi aquades $0,4 \mathrm{ml}$, kelompok II kelompok positif diberi parasetamol 1000mg/50kgBB, kelompok III kelompok perlakuan diberi ekstrak etanol buah mengkudu 200mg/kgBB, kelompok IV kelompok perlakuan diberi ekstrak etanol buah mengkudu 400mg/kgBB dan kelompok V kelompok perlakuan diberi ekstrak etanol buah mengkudu $800 \mathrm{mg} / \mathrm{kgBB}$. Penilaian dilakukan selama satu menit dengan menilai respon mencit berupa melompat dan atau menjilat kakinya sebagai reaksi untuk mengurangi nyeri.Dari hasil percobaan dengan pemberian rangsang panas berupa suhu $55^{\circ} \mathrm{C}$ menunjukkan bahwa respon mencit pada ketiga kelompok perlakuan menurun dibandingkan dengan kontrol
\end{abstract}


positif yang diberi parasetamol.Ekstrak etanol buah mengkudu (Morinda citrifolia L.) memiliki efek analgesik terhadap mencit (Mus musculus).

Kata kunci: Analgesik, Buah mengkudu (Morinda citrifolia L.), Parasetamol.

Sejak zaman dahulu, manusia sangat mengandalkan lingkungan sekitarnya untuk memenuhi kebutuhannya, misalnya untuk makan, tempat berteduh, pakaian, obat, pupuk, parfum, dan bahkan untuk kecantikan. Kekayaan alam di sekitar manusia sebenarnya sangat bermanfaat dan belum sepenuhnya digali, dimanfaatkan, atau dikembangkan. Penduduk Indonesia telah lama mengenal dan menggunakan tanaman berkhasiat obat sebagai salah satu upaya dalam menanggulangi masalah kesehatan. Pengetahuan tentang tanaman berkhasiat obat berdasar pada pengalaman dan keterampilan mengolah tanaman obat yang secara turun temurun telah diwariskan dari satu generasi ke generasi berikutnya. ${ }^{1}$

Penggunaan tanaman obat di masyarakat Indonesia sebenarnya sudah dimulai sejak 350 tahun yang lalu. Di Indonesia, dikenal lebih dari 20.000 jenis tumbuhan obat. Sampai saat ini baru 1000 jenis tanaman yang telah terdata dan baru sekitar 300 jenis yang sudah dimanfaatkan untuk pengobatan tradisional. ${ }^{2}$

Tanaman mengkudu (Morinda citrifolia L.) termasuk dalam tumbuhan obat yang sudah dimanfaatkan untuk pengobatan tradisional. Mengkudu mempunyai beberapa nama seperti Pace (Jawa), Cengkudu (Sunda), Kodhuk (Madura) dan Wengkudu (Bali). Beberapa tahun terakhir ini, tanaman mengkudu mendapat perhatian sangat besar karena adanya fakta empiris yang menyatakan bahwa buah mengkudu berkhasiat dalam meringankan gejala penyakit seperti tekanan darah tinggi, nyeri saat menstruasi, arthritis, kurang nafsu makan, dan atherosklerosis. Secara tradisional, mengkudu diminum dalam bentuk sari buah (jus). Buah mengkudu mengandung xeronine, proxeronine, proxeronase, damnacanthal, nondamnacanthal, asam amino, serta mineral seperti magnesium, dan fosfat. Produk olahan buah mengkudu tidak hanya berbentuk jus atau sari buah saja, tetapi juga berupa serbuk buah tanpa biji yang dikemas dalam kapsul dan banyak dijual di pasar tradisional Indonesia. ${ }^{3-5}$

Kecenderungan untuk memakai tanaman obat pada masyarakat saat ini biasanya berbeda-beda tergantung daerah tempat tinggalnya. Di daerah pedesaan, pemanfaatan tanaman obat masih sering digunakan. Masyarakat perkotaan umumnya sudah jarang memanfaatkan tanaman obat dan lebih beralih kepada obat-obatan sintetik. Obat tradisional yang berasal dari tanaman pada umumnya memiliki efek samping yang lebih rendah tingkat bahayanya dibandingkan obat-obatan sintetik, walaupun tidak semua tanaman obat aman untuk dikonsumsi. Kurangnya pengetahuan dan informasi yang memadai mengenai berbagai jenis tumbuhan yang dipakai sebagai ramuan obat-obatan tradisional untuk pengobatan penyakit tertentu dan cara pembuatannya menjadi masalah dan kesulitan bagi para peminat obat-obatan tradisional sampai saat ini. ${ }^{6,7}$

Menurut Younos et al. (1990), ekstrak mengkudu mempunyai efek analgesik. Dr. Chafique Younos menggunakan ekstrak dari akar mengkudu yang dia ambil dari pengalaman empiris masyarakat Mauritius, Tangatapu, Vietnam, dan Filipina untuk mengatasi nyeri. Di Indonesia sendiri tanaman mengkudu kerap dikonsumsi untuk mengatasi nyeri haid, sakit perut, menambah nafsu makan dan lain-lain. ${ }^{2,8,9}$

Tujuan dari penelitian ini ialah untuk mengetahui ada tidaknya efek analgesik dari ekstrak etanol buah mengkudu (Morinda citrifolia L.) pada mencit (Mus musculus).

\section{METODE}

Desain penelitian ini ialah uji eksperimental yang dilakukan di Laboratorium Farmakologi dan Terapi Fakultas Kedokteran Universitas Sam Ratulangi Manado dari bulan September 
2012 sampai dengan Januari 2013. Subjek penelitian ini ialah 15 ekor mencit (Mus musculus) yang dibagi dalam 5 kelompok, masing-masing kelompok terdiri dari 3 ekor mencit betina. Kelima kelompok tersebut ialah kelompok I kelompok negatif diberi aquades 0,4 $\mathrm{ml}$, kelompok II kelompok positif diberi parasetamol 1000mg/50kgBB, kelompok III kelompok perlakuan diberi ekstrak etanol buah mengkudu 200mg/kgBB, kelompok IV kelompok perlakuan diberi ekstrak etanol buah mengkudu 400mg/kgBB dan kelompok $\mathrm{V}$ kelompok perlakuan diberi ekstrak etanol buah mengkudu 800mg/kgBB. Penelitian ini menggunakan metode rangsang panas berupa suhu 5\%

Penilaian dilakukan selama satu menit dengan menilai respon mencit berupa melompat dan atau menjilat kakinya sebagai reaksi untuk mengurangi nyeri.

\section{HASIL}

Data di bawah ini merupakan hasil pengamatan respon mencit terhadap kelompok hewan uji. Respon mencit yang diamati yaitu frekuensi mencit menjilat kakinya dan atau melompat saat diberikan rangsangan nyeri. Rangsangan nyeri yang digunakan yaitu beaker glass yang dipanaskan dengan water bath pada suhu $55^{\circ} \mathrm{C}$. Frekuensi menjilat dan atau melompat dijumlahkan untuk setiap mencit dan dihitung jumlah rata-rata respon mencit pada setiap kelompok. Rangsangan nyeri diberikan sebelum perlakuan, kemudian setelah perlakuan diberikan rangsangan nyeri pada menit ke 30, 60, 90 dan 120. Hasil penelitian yang lebih lengkap dapat dilihat pada tabel-tabel di bawah ini.

Tabel 1 menunjukkan bahwa rata-rata jumlah respon mencit sebelum pemberian aquades sebanyak 43,7 kali. Pada menit ke30 setelah pemberian aquades, rata-rata jumlah respon mencit sebanyak 43 kali, pada menit ke-60 menjadi 44,3 kali, pada menit ke-90 menjadi 40,7 kali dan pada menit ke-120 menjadi 39 kali.

Tabel 1. Respon Kelompok Kontrol Negatif (Aquades)

\begin{tabular}{|c|c|c|c|c|c|c|c|c|c|c|c|c|c|c|c|}
\hline \multirow{4}{*}{ Subjek } & \multicolumn{15}{|c|}{ Jumlah Respon Mencit } \\
\hline & \multirow{2}{*}{\multicolumn{3}{|c|}{$\begin{array}{l}\text { Sebelum } \\
\text { Perlakuan }\end{array}$}} & \multicolumn{12}{|c|}{ Setelah Perlakuan (Pemberian Aquades) } \\
\hline & & & & \multicolumn{3}{|c|}{30 Menit } & \multicolumn{3}{|c|}{60 Menit } & \multicolumn{3}{|c|}{90 Menit } & \multicolumn{3}{|c|}{120 Menit } \\
\hline & $\mathbf{L}$ & $\mathbf{J}$ & $\mathbf{T}$ & $\mathbf{L}$ & $\mathbf{J}$ & $\mathbf{T}$ & $\mathbf{L}$ & $\mathbf{J}$ & $\mathbf{T}$ & $\mathbf{L}$ & $\mathbf{J}$ & $\mathbf{T}$ & $\mathbf{L}$ & $\mathbf{J}$ & $\mathbf{T}$ \\
\hline I & 0 & 51 & 51 & 0 & 57 & 57 & 0 & 58 & 58 & 0 & 59 & 59 & 0 & 52 & 52 \\
\hline II & 0 & 54 & 54 & 1 & 47 & 48 & 0 & 52 & 52 & 0 & 46 & 46 & 0 & 55 & 55 \\
\hline III & 0 & 26 & 26 & 0 & 24 & 24 & 0 & 23 & 23 & 0 & 17 & 17 & 0 & 10 & 10 \\
\hline Jumlah & & & 131 & & & 129 & & & 133 & & & 122 & & & 117 \\
\hline Rata-rata & & & 43,7 & & & 43 & & & 44,3 & & & 40,7 & & & 39 \\
\hline
\end{tabular}

Ket: $\mathrm{L}=$ Lompat, $\mathrm{J}=$ Jilat, $\mathrm{T}=$ Total

Tabel 2. Respon Kelompok Kontrol Positif (Parasetamol)

\begin{tabular}{|c|c|c|c|c|c|c|c|c|c|c|c|c|c|c|}
\hline \multirow{4}{*}{ Subjek } & \multicolumn{14}{|c|}{ Jumlah Respon Mencit } \\
\hline & \multirow{2}{*}{\multicolumn{3}{|c|}{$\begin{array}{l}\text { Sebelum } \\
\text { Perlakuan }\end{array}$}} & \multicolumn{11}{|c|}{ Setelah Perlakuan (Pemberian Obat) } \\
\hline & & & & \multicolumn{3}{|c|}{30 Menit } & \multicolumn{3}{|c|}{60 Menit } & \multicolumn{3}{|c|}{90 Menit } & \multicolumn{2}{|c|}{120 Menit } \\
\hline & $\mathbf{L}$ & $\mathbf{J}$ & $\mathbf{T}$ & $\mathbf{L}$ & $\mathbf{J}$ & $\mathbf{T}$ & $\mathbf{L}$ & $\mathbf{J}$ & $\mathbf{T}$ & $\mathbf{L}$ & $\mathbf{J}$ & $\mathbf{T}$ & $\mathbf{L} \quad \mathbf{J}$ & $\mathbf{T}$ \\
\hline $\mathrm{I}$ & 0 & 56 & 56 & 0 & 48 & 48 & 0 & 38 & 38 & 0 & 44 & 44 & 040 & 40 \\
\hline II & 0 & 57 & 57 & 0 & 39 & 39 & 0 & 30 & 30 & 0 & 42 & 42 & $0 \quad 39$ & 39 \\
\hline III & 0 & 52 & 52 & 0 & 48 & 48 & 0 & 50 & 50 & 0 & 46 & 46 & $0 \quad 42$ & 42 \\
\hline Jumlah & & & 165 & & & 135 & & & 118 & & & 132 & & 121 \\
\hline Rata-rata & & & 55 & & & 45 & & & 39,3 & & & 44 & & 40,3 \\
\hline
\end{tabular}

Ket: $\mathrm{L}=$ Lompat, $\mathrm{J}=$ Jilat, $\mathrm{T}=$ Total 
Tabel 2 menunjukkan bahwa rata-rata jumlah respon mencit sebelum pemberian obat sebanyak 55 kali. Pada menit ke-30 setelah pemberian obat, rata-rata jumlah respon menurun sebanyak 45 kali, pada menit ke-60 menjadi 39,3 kali, pada menit ke-90 meningkat menjadi 44 kali dan pada menit ke-120 menurun menjadi 40,3 kali.

Tabel 3 menunjukkan bahwa rata-rata jumlah respon mencit sebelum pemberian ekstrak sebanyak 44 kali. Pada menit ke-30 setelah pemberian ekstrak, rata-rata jumlah respon menurun sebanyak 34 kali, pada menit ke-60 meningkat menjadi 39 kali, pada menit ke-90 menurun menjadi 27,3 kali dan pada menit ke-120 meningkat menjadi 32 kali.
Tabel 4 menunjukkan bahwa rata-rata jumlah respon mencit sebelum pemberian ekstrak sebanyak 54 kali. Pada menit ke-30 setelah pemberian ekstrak, rata-rata jumlah respon menurun sebanyak 35,3 kali, pada menit ke-60 meningkat menjadi 40,3 kali, pada menit ke-90 menurun menjadi 27,3 kali dan pada menit ke-120 menjadi 23,7 kali.

Tabel 5 menunjukkan bahwa rata-rata jumlah respon mencit sebelum pemberian ekstrak sebanyak 37 kali. Pada menit ke-30 setelah pemberian ekstrak, rata-rata jumlah respon menurun sebanyak 25,3 kali, pada menit ke-60 menjadi 10,7 kali, pada menit ke-90 meningkat menjadi 25 kali dan pada menit ke-120 menurun menjadi 18,7 kali.

Tabel 3. Respon kelompok mencit yang diberi ekstrak etanol buah mengkudu dosis $200 \mathrm{mg} / \mathrm{kgBB}$

\begin{tabular}{|c|c|c|c|c|c|c|c|c|c|c|c|c|c|c|c|}
\hline \multirow{4}{*}{ Subjek } & \multicolumn{15}{|c|}{ Jumlah Respon Mencit } \\
\hline & \multirow{2}{*}{\multicolumn{3}{|c|}{$\begin{array}{c}\text { Sebelum } \\
\text { Perlakuan }\end{array}$}} & \multicolumn{12}{|c|}{ Setelah Perlakuan (Pemberian Ekstrak) } \\
\hline & & & & \multicolumn{3}{|c|}{30 Menit } & \multicolumn{3}{|c|}{60 Menit } & \multicolumn{3}{|c|}{90 Menit } & \multicolumn{3}{|c|}{120 Menit } \\
\hline & $\mathbf{L}$ & $\mathbf{J}$ & $\mathbf{T}$ & $\mathbf{L}$ & $\mathbf{J}$ & $\mathbf{T}$ & $\mathbf{L}$ & $\mathbf{J}$ & $\mathbf{T}$ & $\mathbf{L}$ & $\mathbf{J}$ & $\mathbf{T}$ & $\mathbf{L}$ & $\mathbf{J}$ & $\mathbf{T}$ \\
\hline I & 0 & 56 & 56 & 0 & 45 & 45 & 0 & 50 & 50 & 0 & 25 & 25 & 0 & 47 & 47 \\
\hline II & 2 & 27 & 29 & 0 & 25 & 25 & 0 & 31 & 31 & 0 & 21 & 21 & 0 & 22 & 22 \\
\hline III & 0 & 47 & 47 & 0 & 32 & 32 & 0 & 36 & 36 & 0 & 36 & 36 & 0 & 27 & 27 \\
\hline Jumlah & & & 132 & & & 102 & & & 117 & & & 82 & & & 96 \\
\hline Rata-rata & & & 44 & & & 34 & & & 39 & & & 27,3 & & & 32 \\
\hline
\end{tabular}

Ket: $\mathrm{L}=$ Lompat, $\mathrm{J}=$ Jilat, $\mathrm{T}=$ Total

Tabel 4. Respon kelompok mencit yang diberi ekstrak etanol buah mengkudu dosis $400 \mathrm{mg} / \mathrm{kgBB}$

\begin{tabular}{|c|c|c|c|c|c|c|c|c|c|c|c|c|c|c|c|}
\hline \multirow{4}{*}{ Subjek } & \multicolumn{15}{|c|}{ Jumlah Respon Mencit } \\
\hline & \multirow{2}{*}{\multicolumn{3}{|c|}{$\begin{array}{l}\text { Sebelum } \\
\text { Perlakuan }\end{array}$}} & \multicolumn{12}{|c|}{ Setelah Perlakuan (Pemberian Ekstrak) } \\
\hline & & & & \multicolumn{3}{|c|}{30 Menit } & \multicolumn{3}{|c|}{60 Menit } & \multicolumn{3}{|c|}{90 Menit } & \multicolumn{3}{|c|}{120 Menit } \\
\hline & $\mathbf{L}$ & $\mathbf{J}$ & $\mathbf{T}$ & $\mathbf{L}$ & $\mathbf{J}$ & $\mathbf{T}$ & $\mathbf{L}$ & $\mathbf{J}$ & $\mathbf{T}$ & $\mathbf{L}$ & $\mathbf{J}$ & $\mathbf{T}$ & $\mathbf{L}$ & $\mathbf{J}$ & $\mathbf{T}$ \\
\hline I & 0 & 62 & 62 & 0 & 42 & 42 & 0 & 39 & 39 & 0 & 24 & 24 & 0 & 30 & 30 \\
\hline II & 0 & 46 & 46 & 0 & 34 & 34 & 1 & 38 & 39 & 0 & 29 & 29 & 0 & 16 & 16 \\
\hline III & 0 & 54 & 54 & 0 & 30 & 30 & 0 & 43 & 43 & 0 & 29 & 29 & 0 & 25 & 25 \\
\hline Jumlah & & & 162 & & & 106 & & & 121 & & & 82 & & & 71 \\
\hline Rata-rata & & & 54 & & & 35,3 & & & 40,3 & & & 27,3 & & & 23,7 \\
\hline
\end{tabular}

Ket: $\mathrm{L}=$ Lompat, $\mathrm{J}=$ Jilat, $\mathrm{T}=$ Total 
Tabel 5. Respon kelompok mencit yang diberi ekstrak etanol buah mengkudu dosis $800 \mathrm{mg} / \mathrm{kgBB}$

\begin{tabular}{|c|c|c|c|c|c|c|c|c|c|c|c|c|c|c|c|}
\hline \multirow{4}{*}{ Subjek } & \multicolumn{15}{|c|}{ Jumlah Respon Mencit } \\
\hline & \multirow{2}{*}{\multicolumn{3}{|c|}{$\begin{array}{c}\text { Sebelum } \\
\text { Perlakuan }\end{array}$}} & \multicolumn{12}{|c|}{ Setelah Perlakuan (Pemberian Ekstrak) } \\
\hline & & & & \multicolumn{3}{|c|}{30 Menit } & \multicolumn{3}{|c|}{60 Menit } & \multicolumn{3}{|c|}{90 Menit } & \multicolumn{3}{|c|}{120 Menit } \\
\hline & $\mathbf{L}$ & $\mathbf{J}$ & $\mathbf{T}$ & $\mathbf{L}$ & $\mathbf{J}$ & $\mathbf{T}$ & $\mathbf{L}$ & $\mathbf{J}$ & $\mathbf{T}$ & $\mathbf{L}$ & $\mathbf{J}$ & $\mathbf{T}$ & $\mathbf{L}$ & $\mathbf{J}$ & $\mathbf{T}$ \\
\hline I & 0 & 30 & 30 & 0 & 40 & 40 & 0 & 7 & 7 & 2 & 17 & 19 & 0 & 12 & 12 \\
\hline II & 0 & 32 & 32 & 10 & 0 & 10 & 8 & 0 & 8 & 24 & 0 & 24 & 0 & 14 & 14 \\
\hline III & 0 & 49 & 49 & 2 & 24 & 26 & 0 & 17 & 17 & 0 & 32 & 32 & 0 & 30 & 30 \\
\hline Jumlah & & & 111 & & & 76 & & & 32 & & & 75 & & & 56 \\
\hline Rata-rata & & & 37 & & & 25,3 & & & 10,7 & & & 25 & & & 18,7 \\
\hline
\end{tabular}

Ket: $\mathrm{L}=$ Lompat, $\mathrm{J}=$ Jilat, $\mathrm{T}=$ Total

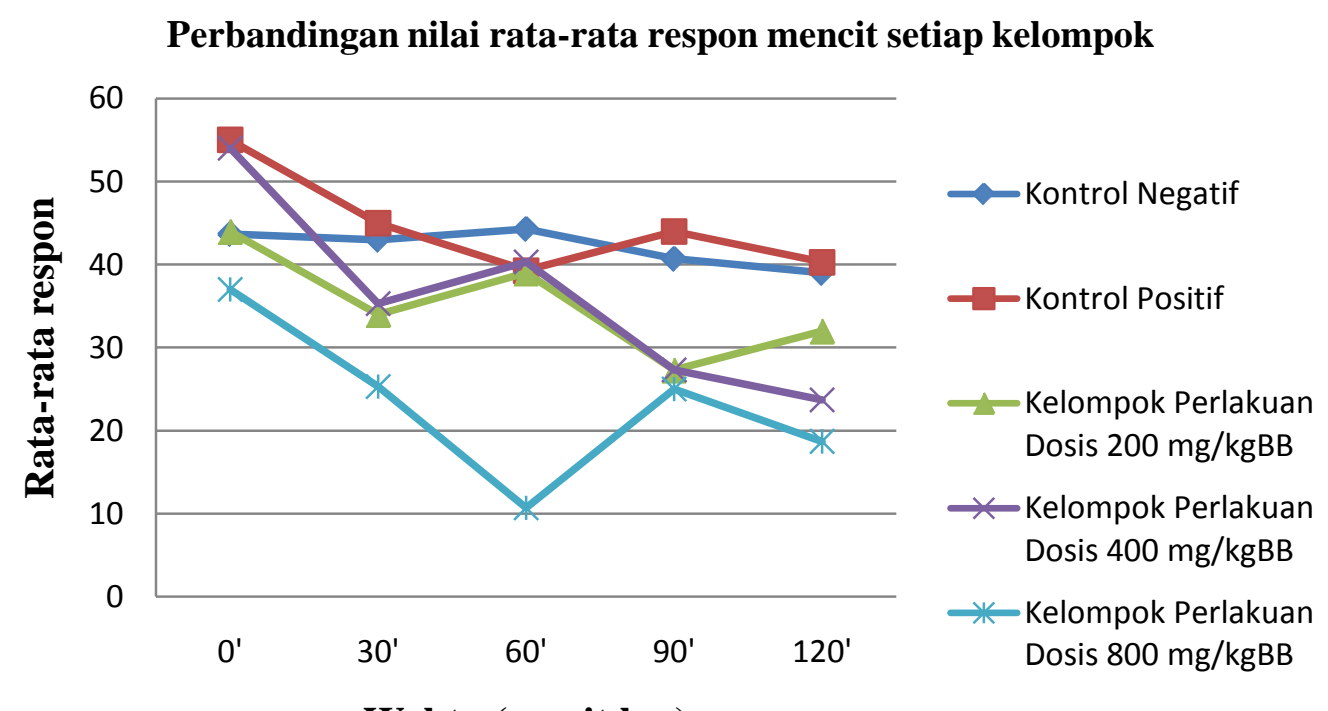

Gambar 1. Grafik perbandingan nilai rata-rata respon mencit kelima kelompok uji.

Pada Gambar 1 menunjukkan nilai rata-rata jumlah respon mencit kelompok kontrol positif/ parasetamol, respon mencit kelompok kontrol negatif/aquades dan respon mencit kelompok eksperimental/ ekstrak etanol buah mengkudu yang terbagi dalam tiga dosis (200 mg/kgBB, 400 $\mathrm{mg} / \mathrm{kgBB}$, dan $800 \mathrm{mg} / \mathrm{kgBB}$ ). Perbandingan grafik nilai rata-rata respon mencit kelima kelompok uji dapat dilihat pada Gambar 3 di bawah ini.

\section{BAHASAN}

Dari hasil pengamatan data ini dapat dilihat penurunan jumlah respon tertinggi pada kelompok kontrol positif sebelum perlakuan dan menit ke-60 hanya sebesar 15,7 kali. Penurunan jumlah respon tertinggi pada kelompok perlakuan dengan dosis $200 \mathrm{mg} / \mathrm{kgBB}$ yaitu sebelum perlakuan dan menit ke-90 ialah 16,7 kali. Penurunan jumlah respon tertinggi pada kelompok perlakuan dengan dosis 400 $\mathrm{mg} / \mathrm{kgBB}$ yaitu sebelum perlakuan dan menit ke-120 ialah 30.3 kali. Penurunan jumlah respon tertinggi pada kelompok perlakuan dengan dosis $800 \mathrm{mg} / \mathrm{kgBB}$ yaitu sebelum perlakuan dan menit ke-60 ialah 26,3 kali. Dari hasil ini dapat dilihat bahwa ekstrak etanol buah mengkudu mempunyai efek analgesik yang lebih kuat 
dibandingkan dengan parasetamol.

\section{SIMPULAN}

Ekstrak etanol buah mengkudu (Morinda citrifolia L.) memiliki efek analgesik terhadap mencit (Mus musculus).

\section{SARAN}

Perlu dilakukan penelitian efek analgesik ekstrak etanol buah mengkudu dengan hewan uji yang lebih banyak, menggunakan pembanding beberapa obat analgesik golongan lain, menggunakan tingkatan dosis yang lebih besar dan menggunakan metode yang berbeda.

\section{UCAPAN TERIMA KASIH}

Kepada penguji 1 dan penguji 2 yang banyak memberi masukan dan kepada semua pihak yang secara langsung maupun tidak langsung memberikan ide dan gagasan sehingga artikel ini bisa dibuat.

\section{DAFTAR PUSTAKA}

1. Sari LORK. Pemanfaatan Obat Tradisional Dengan Pertimbangan Manfaat Dan Keamanannya. Majalah Ilmu Kefarmasian. 2006;3;1-7. Diunduh dari: http://jurnal.farmasi.ui.ac.id/pdf/2006/v03 n01/lusia0301.pdf. Diakses 17 Oktober 2012.

2. Hariana HA. Tumbuhan Obat dan Khasiatnya Seri 2. Jakarta: Penebar Swadaya, 2008; h.5. Diunduh dari: http://books.google.co.id/books?isbn=979 4899577. Diakses 18 Oktober 2012.

3. Winarti C. Peluang Pengembangan Minuman Fungsional dari Buah Mengkudu (Morinda citrifolia L.). Litbang Pertanian. 2005;24(4);149-50.

4. Thomas ANS. Tanaman Obat Tradisional 1. Yogyakarta: Kanisius;1989.h.62. Diunduh dari: http://dc343.4shared.com/download/nAee Mq7f/Tanaman_obat_tradisionalVolu.pdf?tsid=20121107-1836362b5b88b4. Diakses 18 Oktober 2012.

5. Khomasan A. Rahasia Sehat Dengan Makanan Berkhasiat. Jakarta: Kompas;2009.h.3-5. Diunduh dari: http://books.google.co.id/books?isbn=979 7094073. Diakses 18 Oktober 2012.

6. Muhlisah F. Tanaman Obat Keluarga. Jakarta: Penebar Swadaya, 2007; h.5-7. Diunduh dari: http://books.google.co.id/books?isbn=979 0021739. Diakses 18 Oktober 2012.

7. Thomas ANS. Tanaman Obat Tradisional 2. Yogyakarta: Kanisius, 1992; h.9-10. Diunduh dari: http://books.google.co.id/books?isbn=979 4138096. Diakses 18 Oktober 2012.

8. Younos C, Rolland A, Fleurentin J, Lanhers MC, Misslin R, Mortier F. Analgesic and Behavioural Effects of Morinda citrifolia. Planta Med. 1990;56;430-4.

9. Dalimartha S. Atlas Tumbuhan Obat Indonesia. Jakarta: Niaga Swadaya, 2006; h.56-8. Diunduh dari: http://books.google.co.id/books?isbn=979 113314X. Diakses 23 Oktober 2012. 